\title{
Flood risk assessment in Tabasco, Mexico
}

\author{
L. Gama ${ }^{1}$, M. A. Ortiz-Pérez ${ }^{2}$, E. Moguel-Ordoñez ${ }^{1}$, \\ R. Collado-Torres ${ }^{1}$, H. Diaz-López ${ }^{1}$, C. Villanueva-García ${ }^{1}$ \\ \& M. E. Macías-Valadez ${ }^{1}$ \\ ${ }^{I}$ División Académica de Ciencias Biológicas, \\ Universidad Juárez Autónoma de Tabasco, México \\ ${ }^{2}$ Universidad Nacional Autónoma de México, México
}

\begin{abstract}
Floods constitute the worst type of disaster in the South of Mexico, where Tabasco is located. The resulting damages have had the largest economic, social, and environmental consequences. Recently, floods have increased spatially and in magnitude in a drastic way which has become a risk for a great number of the population. This phenomenon would increase due to global warming. Although it is impossible to eliminate floods in the area, the identification of vulnerabilities and the generations of capabilities will protect the population as well as the economic and social infrastructure minimizing their effects. Rainfalls higher than $400 \mathrm{~mm}$ throughout 24 hours are nowadays common in some areas of the State. Tabasco has undergone an important land cover change, mainly because of two activities: oil extraction and cattle ranch affecting natural landscapes, especially wetlands. Satellite images, aerial photos and historical data were reviewed to evaluate changes of the hydrological system related to floods. Due to the increase in extraordinary precipitation events, a risk analysis was carried out to assess the loss of environmental services and to configure vulnerability and risk maps. Results show that some of the infrastructure built to protect urban areas against floods has not been supported with studies related to the natural components of the area, affecting the hydrodynamic of the basin and increasing drastically the risk to the population. Water management, restoration policies and infrastructure alternatives are proposed as adaptation strategies to be able to minimize population risk of floods in the future.
\end{abstract}

Keywords: climate change, hydrology, watersheds, disaster, vulnerability. 


\section{Introduction}

Due to its geographical location, Mexico is exposed to different meteorological and hydro-meteorological severe events such as hurricanes which have generated great economic and environmental costs. They have caused different types of damage to the population, infrastructure, services, and productive systems. This damage has increased due to big amounts of soils and water transportation resulting from deforestation and lack of land-use planning.

Fatalities related to disasters in Mexico have been reduced significantly but they had grown considerably in terms of property damage and economic losses. The National Civil Protection System reported losses of an average of $\$ 700$ million a year between 1980 and 1999; from 2000 to the present, the economic cost of disasters has increased to more than double [1]. This reflects that the infrastructure is at risk and the rising value of economic activities is endangered.

According to studies by Mexican National Water Commission (CONAGUA), there are 1471 basin areas in Mexico, grouped into 722 watersheds. Tabasco is the State where it rains the most in the country; it is located in the Southeast of Mexico, in the coastal area of the Grijalva-Usumacinta Watershed (table 1).

Table 1: $\quad$ Data related to the Grijalva-Usumacinta watershed.

\begin{tabular}{|c|c|c|c|c|c|}
\hline & $\begin{array}{c}\text { Renewable } \\
\text { water } \\
\text { resources } \\
\left(\mathrm{hm}^{3} / \text { year }\right)\end{array}$ & $\begin{array}{c}\text { Population } \\
2008 \\
\text { (millions } \\
\text { of } \\
\text { inhabitants) }\end{array}$ & $\begin{array}{c}\text { Per capita } \\
\text { renewable } \\
\text { water } \\
\text { resources } \\
2008\left(\mathrm{~m}^{3} /\right. \\
\text { inhab/year) }\end{array}$ & $\begin{array}{c}\text { Total mean } \\
\text { natural } \\
\text { surface } \\
\text { runoff a } \\
\left(\mathrm{hm}^{3} /\right. \\
\text { year) }\end{array}$ & $\begin{array}{c}\text { Total } \\
\text { mean } \\
\text { aquifer } \\
\text { recharge } \\
\left(\mathrm{hm}^{3} /\right. \\
\text { year) }\end{array}$ \\
\hline $\begin{array}{c}\text { Southern } \\
\text { Border }\end{array}$ & 157754 & 6.56 & 24043 & 1399 & 18 \\
\hline
\end{tabular}

The National Institute of Ecology (INE) has identified the state of Tabasco as highly vulnerable. There are extreme projections about the consequences of floods due to atypical rains and rise in sea level [2]. These facts and the changes in precipitation patterns make most of the territory vulnerable to more intense floods.

The presence of environmental risk factors depends on the existence of a variety of threats and do to vulnerability of the population in a specific area because climate variability differs on scales of time and space.

The prediction of hydro-meteorological events depends on the existence of long term monitoring systems and high technology instruments and its precision, in some cases, does not exceeds days of forecast.

Today, different natural hazards are expected due to climate change. Mexico is vulnerable to all of them in different areas and several degrees. The constructed scenarios [3] predict different degrees of changes related mainly to increments in temperature and precipitation distribution. Although there are no details regarding rain behavior, scenarios show a decreased tendency according 
to rain in most areas of the country that would not reflect clear dry conditions. This trend would carry important water stress conditions affecting the vegetation cover and agricultural activities in the Southeast of Mexico.

The Grijalva-Usumacinta watersheds, where Tabasco is located, are altogether the biggest ones in Mexico. This means that one third of all the fresh water reservoirs of the country pass through Tabasco. The State has $91,345 \mathrm{~km}^{2}$ that represent $4.7 \%$ of all the Mexican territory and 5\% of the Mexican population. Four of the biggest dams to generate electricity in the country were constructed in the Grijalva River.

There are important environmental impacts associated with oil extraction and cattle ranch which are the main economic activities in Tabasco. These activities have promoted important deforestation that has increased the vulnerability to floods.

In the last century, the construction of dams was considered the main alternative to prevent floods and to develop irrigation systems for agricultural and cattle ranch activities. Today, there are 4000 dams Mexico, 667 of them are big ones, according to the International Commission of Large Dams. A series of four huge hydroelectric dams were built in two of the most important rivers in Mexico, Grijalva-Usumacinta (table 2).

Table 2: Data of the dams on the watershed, the numbers beside the name correspond to the importance of the dam among all the ones that are constructed in Mexico.

\begin{tabular}{|l|c|c|c|c|c|c|}
\hline \multicolumn{1}{|c|}{ Name } & $\begin{array}{c}\text { NAMO } \\
*\end{array}$ & Height & $\begin{array}{c}\text { Construction } \\
\text { date }\end{array}$ & Uses & River & Capacity \\
\hline $\begin{array}{l}\text { Belisario } \\
\text { Dominguez } \\
\text { Angostura (1) }\end{array}$ & 12762 & 147 & 1974 & G & Grijalva & 12762 \\
\hline $\begin{array}{l}\text { Netzahualcoyotl } \\
\text { Malpaso (3) }\end{array}$ & 10596 & 138 & 1964 & G,C & Grijalva & 10596 \\
\hline $\begin{array}{l}\text { Manuel Moreno } \\
\text { Cruz Chicoasen } \\
(20)\end{array}$ & 1632 & 261 & 1980 & G & Grijalva & 1632 \\
\hline $\begin{array}{l}\text { Angel Albino } \\
\text { Corzo Peñitas } \\
(23)\end{array}$ & 1091 & 58 & 1986 & G & Grijalva & 1091 \\
\hline
\end{tabular}

*NAMO Maximum Ordinary Water Level.

Vulnerability studies [4] which have taken into account potential threats are necessary in order to design strategies to protect the population. The data support a diagnostic in relation to the different impacts expected by global climate change. These results and other environmental planning tools such as Ecologic Territory Planning will allow local government decision makers to have feasible data to establish development strategies taking into consideration areas in high risk.

Rates of poverty and marginalization are high in Tabasco. The little development potential and disordered urban growth has caused large numbers of 
people to be exposed to suffer damages from extraordinary hydro-meteorological events. On the other hand, deforestation has increased producing more soil erosion, and a raise of sediment transportation has provoked important modifications on riverbeds compromising their capacity to transport large volumes of water, thereby allowing more frequent floods.

Therefore, the objective is to analyze the environmental threats that have caused disasters in Tabasco. The review of the vulnerability conditions was essential to identify the areas and to understand the causes that could be exposed to an intensification of these conditions with global warming. The goal is to propose measurements against the risk to which thousands of people are exposed today in the State or would be in the near future.

\section{Methodology}

To evaluate the risk of floods, this research identified the natural characteristics of the area and the potential to hydro-meteorological hazards that could represent vulnerability conditions for the local population considering three aspects: 1) historical analysis of hazards in the area related to rainfall data, floods, drought, tropical storms or hurricanes, affecting the population in the watershed; 2) land use changes in the territory, and 3) climate change scenarios to predict future risks.

Literature of the historical sources from the National Historical Archive related to different types of hazards in the region connected to extreme rainfall events was reviewed. The information was registered in a cartographic data base. Maps dated as far back as the XVI century, aerial photos and historical data were reviewed to evaluate the vulnerable areas related to changes in the hydrological system, the infrastructure and population growth.

Temperature and precipitation meteorological data from different sources were recorded for statistical, graphic and cartographic analysis to identify pattern variation. Data from the Global Historical Climatology Network (GHCN) as well as data from meteorological stations (CONAGUA) in southern Mexico were gathered. Monthly precipitation data were converted to a Standardized Precipitation Index and interpolated to form monthly contour maps of the area to model precipitation distribution in the region related to the geographical distribution of the population and the infrastructure.

The historical analysis data as well as the temperature and precipitation information was used to configure maps related to potential hydrometeorological hazards. Using a geographic information system, vulnerability areas were identified, taking into account altitude, hydrology, drainage, soil, precipitation and vegetation. The risk analysis to potential floods took into account the vulnerability data as well as the potential hazards. This map has helped the assessment of data regarding damages as well as the information related to strategies to avoid future disasters related to floods. 


\section{Results}

The climate of Tabasco is hot and humid, with a hydrothermal regime characterized by annual rainfalls of between 1500 and $2000 \mathrm{~mm}$, and mean annual temperatures above $26^{\circ} \mathrm{C}$, with minimums of $20-22^{\circ} \mathrm{C}$ in January, and peaks between $30-34^{\circ} \mathrm{C}$ in May. It has a wind regime predominance of the $\mathrm{E}-$ $\mathrm{NE}$, with an average speed of between 4 and $6 \mathrm{~m} / \mathrm{sec}$, sometimes longer than $8 \mathrm{~m} / \mathrm{sec}$.

The Grijalva-Usumacinta watershed has undergone dramatic deforestation and important environmental impacts due to unplanned development policies related to agricultural, cattle ranch and oil exploitation activities. Historical literature reviews show that most of the infrastructure constructed to protect population against floods had not been supported by studies taking in account the vulnerability related to the natural characteristics of the area. Natural hazards

Table 3: Example of hydro-meteorological events related to disasters in the area.

\begin{tabular}{|c|c|c|c|c|c|}
\hline Area & Dates & $\begin{array}{c}\text { Type of } \\
\text { contingency }\end{array}$ & Event & $\begin{array}{l}\text { Classification } \\
\text { of the event }\end{array}$ & Notes \\
\hline $3 / 17$ & $\begin{array}{c}22-24 / 9 / \\
2002\end{array}$ & $\mathrm{D}$ & $\mathrm{L}$ & $\mathrm{H}$ & $\begin{array}{l}\text { Atypical } \\
\text { rain }\end{array}$ \\
\hline $7 / 17$ & $4 / 10 / 2003$ & E & S & $\mathrm{H}$ & TS "Larry" \\
\hline $14 / 17$ & $5 / 10 / 2005$ & E & S & $\mathrm{H}$ & TS “Stan" \\
\hline $1 / 17$ & $\begin{array}{c}28-31 / 1 / \\
2006\end{array}$ & $\mathrm{CC}$ & I & $\mathrm{H}$ & $\begin{array}{l}\text { Atypical } \\
\text { rain }\end{array}$ \\
\hline $1 / 17$ & $2-4 / 6 / 2006$ & $\mathrm{CC}$ & $\mathrm{L}$ & $\mathrm{H}$ & $\begin{array}{c}\text { Torrential } \\
\text { rain }\end{array}$ \\
\hline $13 / 17$ & $1 / 2007$ & $\mathrm{D}, \mathrm{E}$ & $\mathrm{L}$ & $\mathrm{H}$ & \\
\hline $16 / 17$ & $21 / 8 / 2007$ & $\mathrm{E}$ & $\mathrm{H}$ & $\mathrm{H}$ & $\begin{array}{c}\text { Hurricane } \\
\text { Dean }\end{array}$ \\
\hline $16 / 17$ & $12 / 9 / 2007$ & $\mathrm{CC}$ & Drought & $\mathrm{H}$ & \\
\hline $14 / 17$ & $\begin{array}{c}28 / 29 / 10 / \\
2007\end{array}$ & $\mathrm{E}$ & I & $\mathrm{H}$ & \\
\hline $16 / 17$ & $10 / 2007$ & $\mathrm{D}$ & I & $\mathrm{H}$ & \\
\hline $6 / 17$ & $4 / 11 / 2007$ & $\mathrm{E}$ & $\mathrm{L}$ & G & $\begin{array}{l}\text { Landslide } \\
\text { correction }\end{array}$ \\
\hline $5 / 17$ & $6 / 7 / 2008$ & E & I & $\mathrm{H}$ & \\
\hline 17 & $25-29 / 9 / 2008$ & E & $\mathrm{L}, \mathrm{I}$ & $\mathrm{H}$ & \\
\hline $15 / 17$ & $\begin{array}{l}21 / 9 / 2008 \text { to } \\
27 / 10 / 2008\end{array}$ & D & I & $\mathrm{H}$ & \\
\hline \multicolumn{6}{|c|}{$\begin{array}{l}\text { 17- on area column is equal total of municipalities; } \\
\text { D-Disaster, E-Emergency; CC Climatologic contingency; } \\
\text { L-Rain, I-Floods, S-Hurricane, L-Landslide; H-Hydro-methodological, } \\
\text { G-Geology }\end{array}$} \\
\hline
\end{tabular}


especially the ones related to winter storms and atypical tropical storms have increased in presence, magnitude and extension through the last two decades (table 3).

Tabasco has 43 meteorological stations with data in a range from 5 to 52 years. The oldest one is from 1950. Only sixteen stations had at least a period of 30 years of continuous data, those were selected for the analysis. The given information was validated to find out the duration of extreme events. An increase in the number of days of atypical tropical and winter storms have had place especially in October and November, fig. 1. Almost every year during the last two decades, rains have overflowed riverbeds, mainly due to the presence of tropical storms in the Caribbean area.

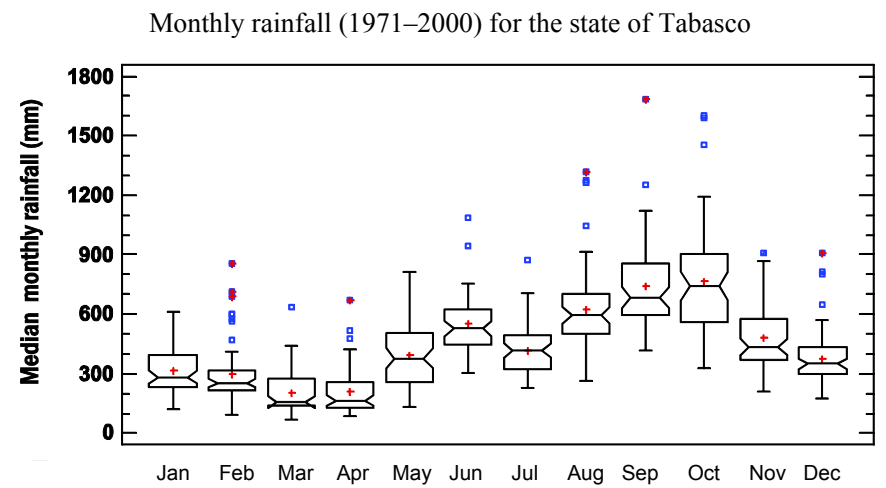

Figure 1: Standard deviations of monthly rainfall meteorological data of the state of Tabasco.

Regarding floods, the one registered on October 2007 affected large areas of Tabasco $(70 \%)$ and some villages of Chiapas. The rainfall bypassed $600 \mathrm{~mm}$ in three days, more than $400 \mathrm{~mm}$ occurred on $28^{\text {th }}$ of October. $600 \mathrm{~mm}$ regularly is the total rain fall for a rainy month, the highest previous record on 24 hours was above $300 \mathrm{~mm}$ in the region. All rivers were overflow as well as lakes and lagoons; it took more than a month to recover natural fluxes.

General data related to the watershed and the population was gathered to identify and locate population at risk (tables 4 and 5). Data shows that there is a large dispersion of the population and flood impacts are equally serious on urban and rural areas. However it is easier to assist urban population. Most of these developments are located below eight meters of altitude (more than $50 \%$ of the territory is below this level). The CONAGUA has just determined that constructions have to be built over the contour line of ten meters to be risk free and has issue a recommendation for the development of new suburban areas. Future and existing protection infrastructure for urban areas are below the designated contour and will be raise up to ten meters for protection against future and existing floods. 
Table 4: $\quad$ Population and infrastructure data.

\begin{tabular}{|c|c|}
\hline \multicolumn{2}{|c|}{ Watershed Data } \\
\hline Normal annual precipitation 1971-2000 & $1846 \mathrm{~mm}$ \\
\hline Mean surface runoff & $139739 \mathrm{hm}^{3} /$ year \\
\hline Number of aquifers & 23 \\
\hline Mean aquifer recharge & $18015 \mathrm{hm}^{3} /$ year \\
\hline Per capita renewable water resources & $200824043 \mathrm{~m}^{3} /$ inhab/year \\
\hline Per capita renewable water resources & $203021041 \mathrm{~m}^{3} /$ inhab/year \\
\hline Number of municipalities & 138 \\
\hline Total population & 20086561406 inhabitants \\
\hline Urban & 3322559 inhabitants \\
\hline Rural & 3238847 inhabitants \\
\hline Total population & 20307497619 inhabitants \\
\hline Tabasco data & 17 \\
\hline Number of municipalities & 20082045247 inhabitants \\
\hline Total population & 1124351 inhabitants \\
\hline Urban & 920896 inhabitants \\
\hline Rural & 20302168004 inhabitants \\
\hline Notal population & 2095 mm \\
\hline
\end{tabular}

Table 5: $\quad$ Population growth of the watershed.

\begin{tabular}{|c|c|c|c|c|c|c|}
\hline $\begin{array}{c}\text { State/ } \\
\text { region }\end{array}$ & $\begin{array}{c}\text { Population } \\
2000\end{array}$ & $\begin{array}{c}\text { Population } \\
2008\end{array}$ & $\begin{array}{c}\text { Mainland } \\
\text { surface } \\
\text { area } \\
\left(\mathrm{km}^{2}\right)\end{array}$ & $\begin{array}{c}\text { Population } \\
\text { density in 2008 } \\
\left(\begin{array}{c}\text { inhabitants/k } \\
\left.\mathrm{m}^{2}\right)\end{array}\right.\end{array}$ & $\begin{array}{c}2007 \\
\text { GDP } \\
(\%)\end{array}$ & $\begin{array}{c}\text { Municipalities } \\
\text { In this area } \\
\text { (number) }\end{array}$ \\
\hline Chiapas & 3920892 & 4483595 & 73178 & 61 & 1.70 & 118 \\
\hline Tabasco & 1891829 & 2045247 & 24743 & 83 & 3.00 & 17 \\
\hline $\begin{array}{l}\text { Southern } \\
\text { Border }\end{array}$ & 6561406 & 101231 & & 65 & 4.76 & 138 \\
\hline
\end{tabular}

Seventy percent of the state is characterized for being in coastal plains with a dynamic hydrography, in wetlands with poor drainage soils that yearly expose the territory to mild floods. Several effects are expected to occur in the near future related to climate change on the State in a region with high risk to floods, fig. 2. An example of these extraordinary precipitation events is that in less than a decade, there have been four important flood events that caused severe disasters linked to intense winter rainfalls that affected almost $70 \%$ of the State in 2007.

Climate change emission sceneries forecast for this area [3] indicates a possible increase of up to $4^{\circ} \mathrm{C}$ and an expected decrease on annual rainfall of $400 \mathrm{~mm}$ that would be affecting all physical systems. However rainfall data do not indicate a decline on rain, they show a variation on seasonal distribution and the presence of atypical rain events. 


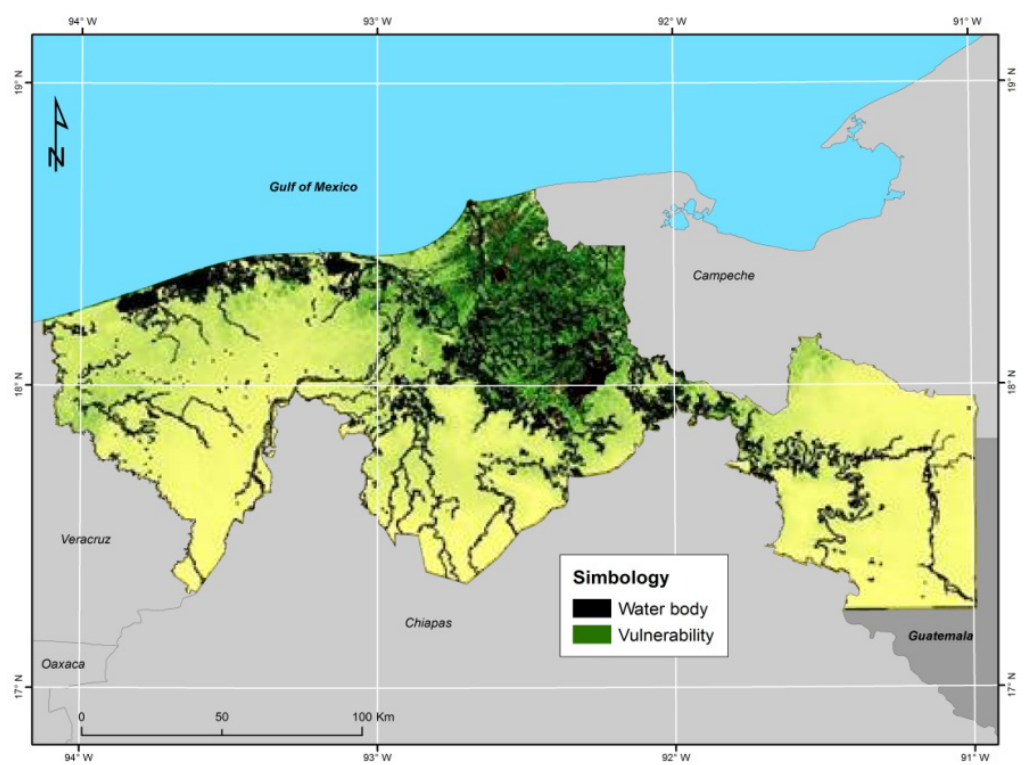

Figure 2: $\quad$ Map developed from the risk analysis.

\subsubsection{Discussion}

Just from the last months of 2006 to the end of 2010, the watershed of the Grijalva-Usumacinta Rivers has had six extreme climatic phenomena of several days with almost continuous, very intense rains. The magnitude of the events had not been reported over 47 years in southeast Mexico (157\% to $188 \%$ over the standard). They have caused overflows of rivers on low areas and the flood of large extensions. 2010 has been considered the rainiest year so far recorded. In a near future, an increase on precipitation is expected due to Climate Change.

Data shows that hydro-meteorological threats are greater than before due to an increase on extraordinary rainfall events that have caused major disasters with important development reversals, even before climate change scenarios were considered.

Based on the vulnerability assessment, flood events have been traditionally expected in this area, but lately, most of the State has already experienced an increase on their magnitude and extension. There are high possibilities to have more of them as it can be observed in the map, (fig. 2).

The expected risk for the population is based on vulnerability and threats that have increased because the infrastructure built and planned to prevent floods did not consider the physical characteristics of the region.

The construction of the dams to control flooding and promote irrigation and the subsequent decision to use them to generate electricity, after each flood event new infrastructure has been constructed to address specifically the area damaged.

This policy of constructing infrastructure has only resulted on more risk for the population because the result of its application is reflected on a modification 
of the area that would undergo the next flooding event or the increase on the magnitude of it, due to a collapse of the natural systems to adjust to these changes.

Vulnerability and risk assessment studies are necessary to design strategies to protect population. The data collected has given support for a diagnostic in relation to the different expected impacts that would increase by global climate change. The CONAGUA plans to redirect riverbeds that reach dense populated areas in order to reduce risk based on an Integral Program against Floods with an approximate investment of 2,060 million pesos to protect around 370,000 inhabitants. To conclude, these results and the ecological territorial planning tools will allow local government decision makers to have feasible data to establish development strategies taking into consideration areas in high risk.

\section{References}

[1] Comisión Nacional del Agua (National Water Commission of MexicoCONAGUA), Estadísticas del agua, Secretaría del Ambiente y Recursos Naturales. México, 2010.

[2] Hernández Santana, J. R., M. A. Ortiz Pérez, A. P. Méndez Linares \& L. Gama Campillo, Morfodinámica de la línea de costa del estado de Tabasco, México: tendencias desde la segunda mitad del siglo XX hasta el presente. Investigaciones Geográficas, Boletín del Instituto de Geografia. UNAM, 65:7-21, 2008.

[3] Magaña Rueda, V., A. Baldemar Méndez, E. Caetano dos Santos, J. M. Méndez Pérez \& E. Pérez Pérez, Escenarios de cambio climático y tendencias en la zona del Golfo de México (Chapter 6). Adaptación a los impactos del cambio climático en los humedales costeros del Golfo de México Vol. II, ed. B. Friedman. INE/SEMARNAT: Mexico. pp. 569-673, 2009.

[4] Ortiz-Perez M.A., J.R. Hernandez-Santana, J.M. Figueroa Mah Eng \& L. Gama Campillo, Tasas de avance transgresivo y regresivo en el frente deltaico tabasqueño: en el periodo comprendido del año 1995 al 2008 (Chapter 13). Vulnerabilidad de las zonas costeras mexicanas ante el Cambio Climatico, ed. Botello V., S. Villanueva, J. Gutierrez \& J.L. Rojas Galaviz, INE/SEMARNAT: Mexico, pp. 305-323, 2010. 